\title{
Teaching Management at Technical Universities, Business Reality in the Academic Environment
}

\author{
V. Baroch, B. Duchoň, V. Faifrová, Z. Říha
}

\begin{abstract}
Students of technical universities often do not understand why their studies should include learning management skills (in addition to the study of economics). However, not only the experience of graduates but also the requirements of their future employers show that education in the field of the management should provide training, skills and practical testing. It is only a matter of time before graduates of technical university take up leading positions or become part of a team working on some complicated technical problem. A classical technical education is no longer sufficient and, above all, it is employees with knowledge of economics and with managerial skills, specifically soft skills that come to the fore.

It is evident from ample experience that people's individual dispositions play a role in learning soft skills, but many of these skills can also be acquired by progressive training. The question is which form of teaching to choose to enable necessary skills to be learned, without at the same discouraging students by offering them potentially unattractive courses. These are the issues that will be treated in this paper.
\end{abstract}

Keywords: management, business requirements analysis, teaching, business simulation.

\section{Introduction}

The solution of any problem must be based on a detailed analysis. Crucial information concerns the extent of the need for various skills required by the employer. CTU in Prague has been carrying out surveys among its graduates over a long period, as the following text will show. The results of two longterm surveys are in strong agreement. In response to questions about which knowledge and skills they use most, graduates begin by mentioning technical knowledge (93\% of the respondents), but this is followed immediately by communication skills and skills for dealing with people $(78 \%)$ [1]. The list of skills to be worked on in the years at the university begins with foreign languages; work with information technology and practical skills are next in the list, followed by managerial skills (leadership, presentation, teamwork and social competences) [1]. These findings are illustrated in the graphs 1, 2 .

A second way to study the need for managerial skills is to pose questions directly to the personnel managers of businesses employing CTU graduates. As Petr Fiala, former president of the Conference of Rectors said: "Business should mainly play a substantially larger role in education quality assessment. Feedback must exist of the type: You have prepared them poorly, or: The graduates cause us the following problems." [2]

This feedback was the target for the second part of the survey. 35 businesses took part in the survey. They were asked about the particular skills of graduates: on one hand the real level of skills of the

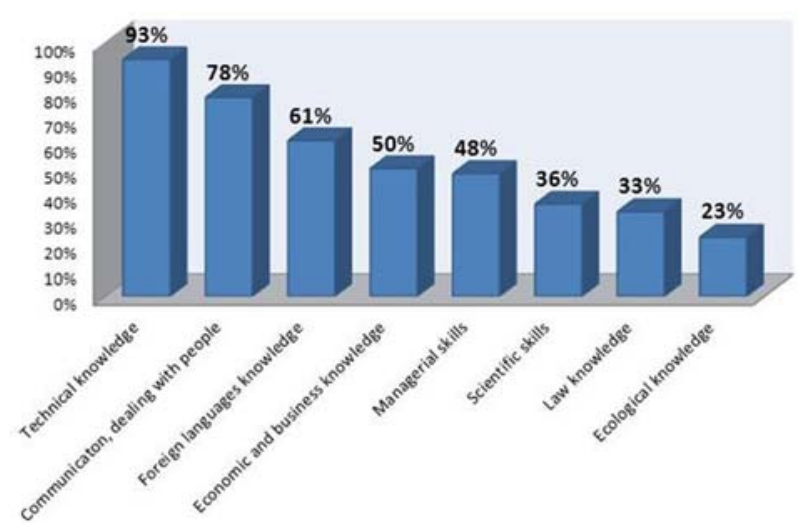

Graph 1: Knowledge used by graduates of the CTU in their work (perentage of graduates using each type of skill), source [1]

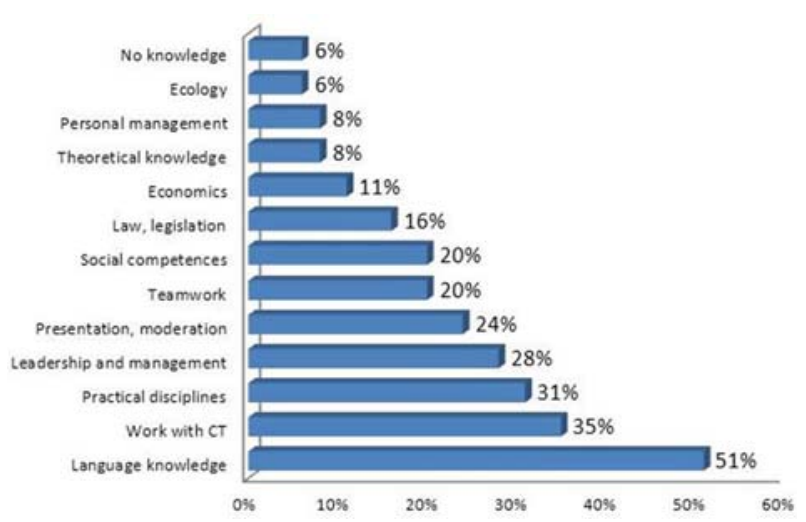

Graph 2: Skills that graduates had to work on extensively after graduation, source [1] 
graduates, and on the other hand the level of skills required by the business. Thus the survey answers the questions: How does an business evaluate particular skills, and to what extent does it require them. This focuses attention on skills that are required, but not obtained by business. These are above all foreign language skills, soft skills and issues of decision-making and business economics. The survey validates the original premise that the labour market requires above all graduates with a technical education supplemented by management and economic knowledge and skills, all supported by knowledge of at least one foreign language.
The results of the survey are illustrated in the graphs 3 .

The graph shows selected skills of graduates of the Faculty of Transportation Sciences of CTU in Prague, as assessed by their employers. All of the skills are situated above the diagonal of the graph, which means that employers require these skills at a higher level than they really obtain. This is true above all for soft skills and analytical thinking. Similarly, the following graph shows that businesses also seek additional management skills, above all decision-making and exact methods for use in decision-making.

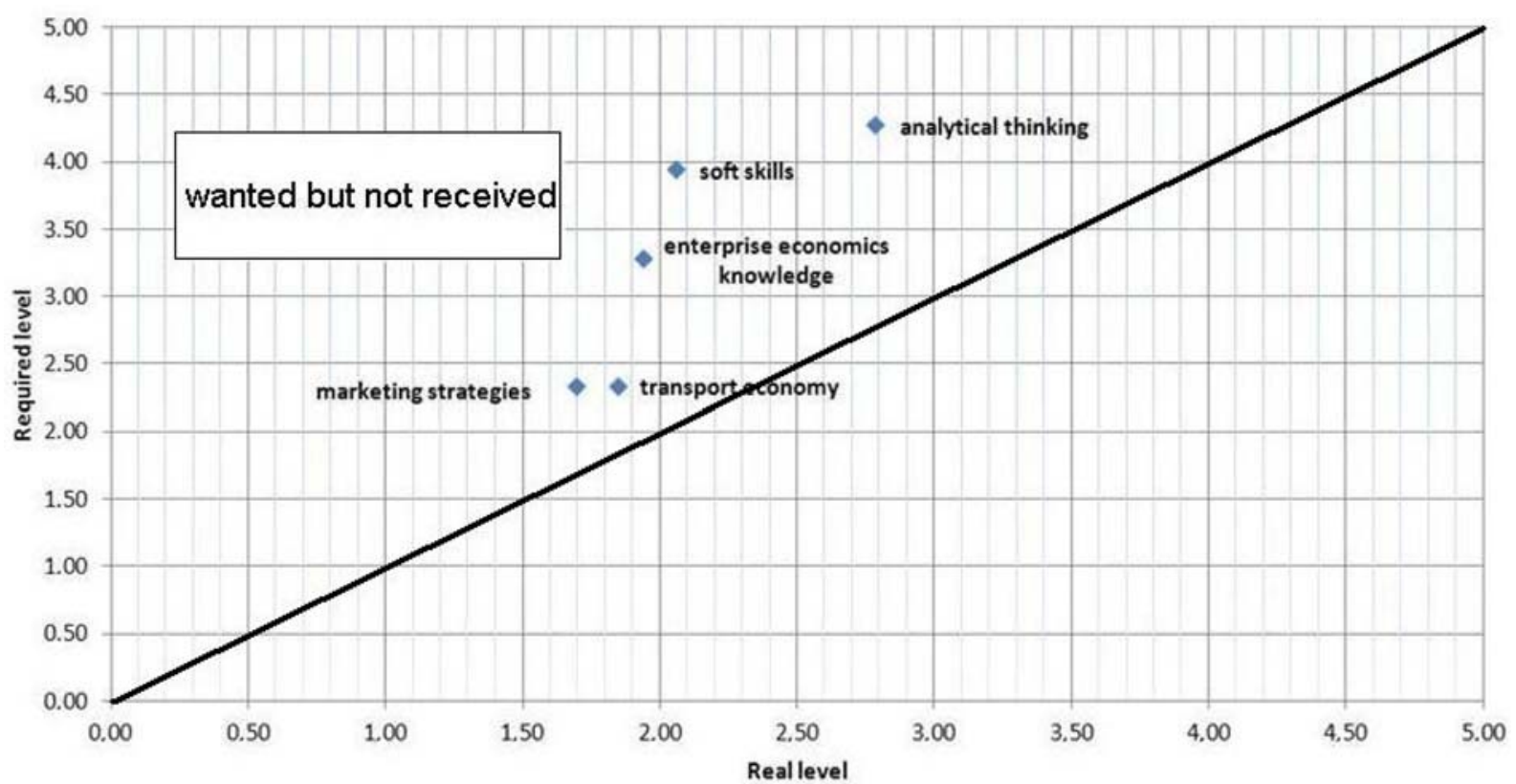

Graph 3: Assessment by their employers of the skills of graduates of the Faculty of Transportation Sciences of CTU in Prague, source [1]

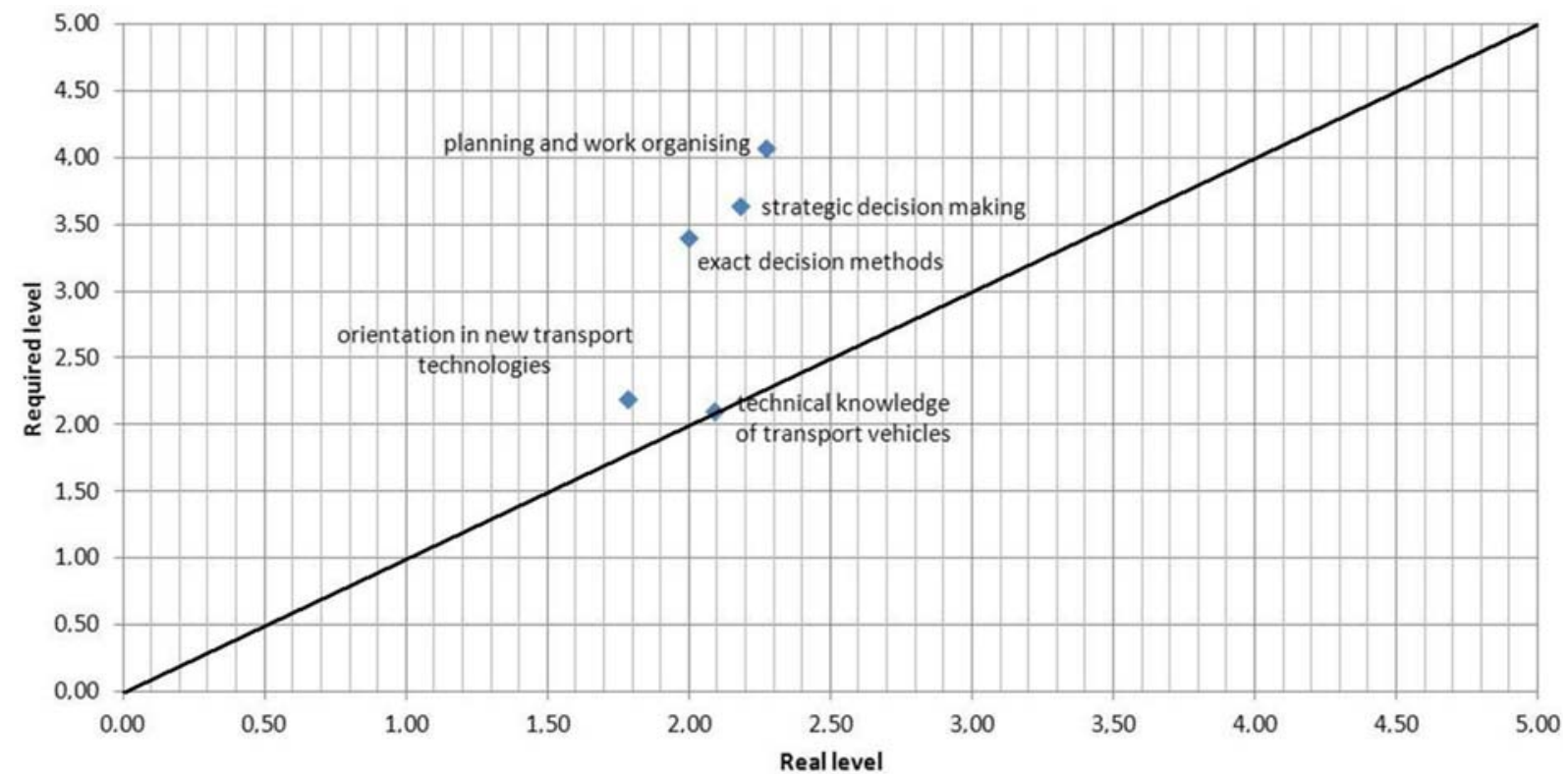

Graph 4: Assessment of the skills of graduates of the Faculty of Transportation Sciences of CTU in Prague by their employers, source [1] 
It should be pointed out that the conclusions from our survey match the conclusions of similar projects implemented at other technical universities. It also follows from these surveys that businesses require management skills to be trained at universities (in-service training courses are an additional expense for business companies [3]). However, businesses should realize that they need to provide financial and material support for the implementation of managerial "laboratory teaching" at technical faculties. The businesses also mentioned that while technical skills can be acquired within half a year of work experience, soft skills can require much more time [4].

\section{Management conception}

Until this point we have used the concept of management and the concept of hard and soft elements. However, the word "management" is widely used to express a variety of concepts, but the practical meaning of the word is not sufficiently well understood. Management should be understood as a broadly based field in which many disciplines interpenetrate, from mathematics to psychological factors (see Figure 1).

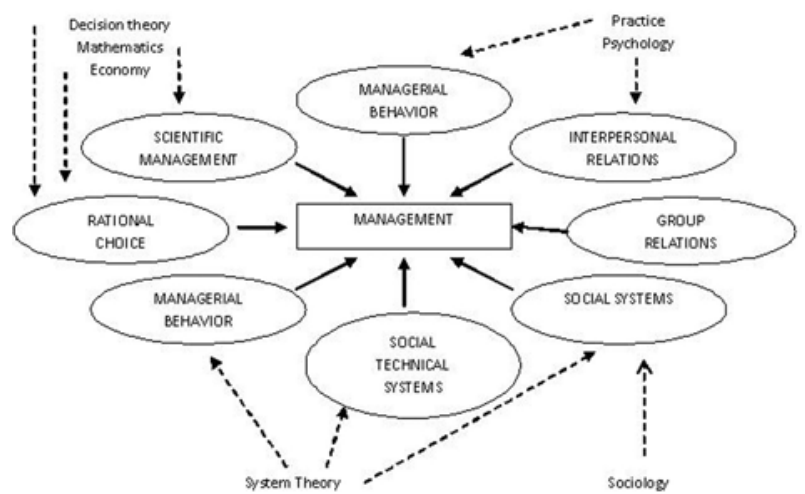

Fig. 1: Penetration of disciplines, source [5]

Many business managers confirm what is taught e.g. at CTU in Prague and at other technical universities. Some opinions from this field can be cited [6]. P. Kafka, President of the Czech Managerial Association, affirms the width of disciplines needed for management. He points out that it is necessary "to aim at creativity, at the acceptance of new disciplines, at links between technical disciplines and other disciplines, e.g. economics and the arts". Kafka argues that it is essential "to join the ability to assess the offers in the whole production context, from the technical viewpoint and from the viewpoint of cost/price".

In the next part of the article we will concentrate on ways to make the teaching of management more attractive, and ways to adjust it to the practical requirements of business life. A priority is to transfer business practice to the laboratory conditions of a university. In teaching that is organized in this way, the main accent should be on teamwork, and on the simulation of the business environment.

\section{Business simulation}

It is essential for students to master the integration of managerial activities, so that they can apply this integration both in project management and in business management. The problem described in this paper can provide a basis for a general idea of a draft concept for management teaching for master's students. The main problem is how to transfer real situations into academic teaching. One way is to simulate the operation of a real business in management teaching.

The simulation itself does not solve a management problem by reaching a strict conclusion. However, it provides support for the final decision, which must be made by the decision-maker, i.e. the manager responsible for managing the company. The implementation is realized by means of a management game that simulates business activities.

The students influence the result of the simulation on the basis of their actions, so that the simulation employs them actively in business management, and teaches them to think strategically. Students take active decision steps based on changes in the system environment, and also based on the changes in the learning curve of the student-decision-maker's knowledge. Students try various ways, and evaluate the results of their decisions. Simulations are appropriate where students learn to solve problems, to integrate information and to react to changes in environment, including the risk that the business may collapse.

The simulation can take the form of electronic financial models for business decision-making, or can take the form of a contact board game. Both forms are based on simulating business processes that are very close to the way real companies operate. Teamwork should be an essential element.

The concept of the business simulation board game is not based on the virtual reality of computer applications. It attempts to recreate a real contact situation from everyday business activities. Besides specialist knowledge, students learn face-to-face how to behave with other people. They also learn teamwork, and to take the individual responsibility for the results of the working group. Students improve in team communication and in operational decisionmaking, and they learn to take a personal role in the team. They work on their presentation skills and they have to react to the questions of the lecturer and of their teammates. The lecturer is a part of the game; he functions as a consultant, coordinator, auditor and supervisor. 
Software versions of management games have been becoming increasingly popular all over the world, because they are able to create a very real business environment in an e-learning form. They enable a trained participant to experience real situations from everyday business practice. A great advantage of management games is that they save time, because simulation can be used in a remote form via the Internet. This makes simulations highly suitable for teaching students by distance study. Worldwide experience has shown that this method using competition provides efficient motivation for active work. The team members meet regularly for business meetings and, thanks to e-learning and the communication technologies that have been developed, the meetings can take the very modern and desirable form of a video conference. Experience of teamwork through videoconferencing is nowadays in great demand in preparation for carrying out the time-demanding profession of a top manager.

Software business simulations depend greatly on mathematical methods that express thousands of complicated relations among hundreds of simulated elements.

The following part of the text is devoted to our experience of working with students using the board version of a business management simulation. A software version is under preparation.

\section{Experience from management teaching for technically-oriented students through business simulation}

The concept of unique management contact business simulation (SIM) was developed on the basis of our experience of teaching management at a technical university, with emphasis on the practical requirements of MSc graduates. The chosen approach was further tested in the pilot version with a sample of approximately 130 technically-oriented students, according to the following process:

1. After the teams have been formed, each student team was given a functioning virtual company in the form of a board game, but without a company management.

2. The starting state of the company was the same for all, and its further fate depended fully on the team's decisions (at the beginning of each laboratory seminar the lecturer distributed the components of the board game according to the balances recording the movements of assets and liabilities from the preceding seminar).

3. In this way, a certain competition element among the student teams was incorporated into the implementation, and above all the need for good team cooperation.

4. The students took on the role of top managers of a virtual company, and took on responsibility for the further running of "their" company.

5. During the seminars, the teams led their virtual company according to established rules, which were laid down in the game manual, for a predefined period of time. At certain times they were able to direct and manage the operation of the company.

6. Each team made decisions e.g. about the capital structure of the company, and made long-term production plans and research programs.

7. All decisions were transparent, as the simulation took place in the form of a board game.

For the evaluation we used the opinions of the target group of an anonymous sample of 128 students out of those who had taken part in our laboratory verification of the business simulation game. In this way quality feedback was acquired. The sample comprised in an equal ratio all the main study profiles at the Faculty of Transportation Sciences of CTU in Prague, including 29 students from the part-time study programme.

The sample of 128 addressed students was segmented into 2 disjoint classes, with a total of 7 segments:

- $1^{\text {st }}$ class:

1. Men

2. Women

- $2^{\text {nd }}$ class:

3. Students of the profile Transportation Systems and Technology

4. Students of the profile Air Traffic Control and Management

5. Students of the profile Management and Economics of Transportation and Telecommunications

6. Students of the profiles Engineering Informatics of Transportation and Communication, Intelligent Transport Systems, Security of Information and Telecommunication Systems

7. Part-time students

The students were asked to respond to 10 questions through an anonymous questionnaire. They were able express their experience and opinions through a free text, after passing through the pilot project. To summarize the most substantial results, we can state that $93 \%$ of the respondents greatly welcome this form of innovation, $74 \%$ would also add the SW version of the business simulation to the teaching programme, $5 \%$ do not know, and only $2 \%$ were in favour of preserving the traditional form of teaching. $90 \%$ of the respondents expected to gain better employment on the labour market after com- 
pleting the innovated course. $77 \%$ favoured further teaching beyond the number of lessons at present allocated for this subject. A detailed overview of the survey is published at the URL http://www.esim.cz.

\section{Conclusion}

The commercial sector calls for better preparation of graduates of technical universities in the field of leading practical projects, team decision-making, strategic management of operations and entire businesses. Students and graduates of CTU in Prague have good specialist and technical knowledge. However the development of soft skills and practical skills is usually not adequately provided at the university. Most businesses support the idea that young people should already acquire these skills during their university studies. The teaching concept should be as close as possible to business practice. Students should therefore adopt teamwork and project work as much as possible while they are still at the university. A team approach is nowadays used increasingly in all fields. This trend is related to the need for rapid and efficient changes in decision-making. Appropriate team forming is a condition for efficient and successful business functioning.

The key competences developed in the framework of management classes should include the ability to assert oneself and promote one's ideas, the art of teamwork and team leadership, the ability to reach decisions independently, to integrate easily and rapidly into the ever-changing economic environment, including knowledge of business terminology in English.

Teaching based on business simulation enables business reality to be implemented into the university environment. Although this type of teaching has been increasingly required by the business companies in which future graduates will be employed, there is still inadequate provision. Moreover, a survey among 128 students who participated in the laboratory test showed clearly that students are interested in this form of innovation.

Commercial courses offered in this field for company employees are generally much more expensive than early preparation during students' university studies, and they are less efficient.

\section{Acknowledgement}

The study reported in this paper was supported by the European Union and co-funded by the Social Fund and by the budget of the Capital City of Prague (project no. CZ.2.17/3.1.00/33309, "An innovative management education technique for better prepara- tion of technical college graduates entering the labour market").

\section{References}

[1] Šafránková, J.: Hodnocení a posuzování kvality výuky z pohledu absolventů C̆VUT a z hlediska požadavků organizací. Praha : 2010.

[2] http://ekonom.ihned.cz/ c1-47081190-prilis-magistru-malo-bakalaru

[3] Hay Group: Prüzkum absolventu technických vysokých škol. studie pro VUT Brno, Hay Group, 2006.

[4] Průzkum požadavků zaměstnavatelů na absolventy technických a přírodovědeckých obor. 2009. http://ipn.msmt.cz/data/uploads/portal/ Pruzkum_pozadavku_zamestnavatelu.pdf

[5] Duchoň, B., Šafránková, J.: Management. Integrace tvrdých a měkkých prvků řízení. Praha : C. H. Beck, 2008.

Ing. Václav Baroch

Phone: +420224359168

E-mail: xbaroch@fd.cvut.cz

Department of Economics and Management of Transport and Telecommunications

\section{CTU FTS}

Horská 3, 12803 Praha 2

Prof. Ing. Bedřich Duchoň, CSc.

Phone: +420224359155

E-mail: duchon@fd.cvut.cz

Department of Economics and Management of Transport and Telecommunications

\section{CTU FTS}

Horská 3, 12803 Praha 2

Ing. Veronika Faifrová, PhD.

Phone: +420224359165

E-mail: faifrova@fd.cvut.cz

Department of Economics and Management of Transport and Telecommunications CTU FTS

Horská 3, 12803 Praha 2

Ing. Zdeněk Ř́ha, PhD.

Phone: +420224359156

E-mail: riha@fd.cvut.cz

Department of Economics and Management of Transport and Telecommunications CTU FTS

Horská 3, 12803 Praha 2 